\title{
Metazoan Parasites of the Mediterranean Garfish Belone belone gracilis (Teleostei: Belonidae) as a Tool for Stock Discrimination
}

\author{
Manel Châari*, Mariam Feki, Lassâd Neifar \\ Laboratoire de Biodiversité et Ecosystèmes Aquatiques, Département des Sciences de la vie, Faculté des \\ Sciences de Sfax, Université de Sfax, Sfax, Tunisie \\ Email: htchaari.m@gmail.com
}

Received 24 June 2015; accepted 26 July 2015; published 29 July 2015

Copyright (C) 2015 by authors and Scientific Research Publishing Inc.

This work is licensed under the Creative Commons Attribution International License (CC BY). http://creativecommons.org/licenses/by/4.0/

(c) (i) Open Access

\section{Abstract}

The aim of the present study was to provide a current survey of metazoan parasites of the Mediterranean garfish Belone belone gracilis Lowe, 1839 off Tunisian coast and their potential use as biological tags for discriminate stocks. Parasitological analysis of 453 specimens of $B$. b. gracilis along the eastern Tunisian coast revealed the presence of ten species of metazoan parasites: one monogenean Axine belones Abildgaard, 1794; four digeneans Lecithostaphylus retroflexus (Molin, 1859), Tergestia acanthocephala (Stossich, 1887) Stossich, 1899, Aponurus laguncula Looss, 1907 and Condylocotyla pilodora (metacercaria) Pearson et Prévot, 1985; one copepod Bomolochus bellones Burmeister, 1835; two isopods Irona nana Schioedte et Meinert, 1884 and Nerocila orbignyi (Guérin-Méneville, 1832); 1 acanthocephalan Telosentis exiguus (Von Linstow, 1901) and one nematod Anisakid larvae. Discriminant analysis using parasites as biological tags, allowed identifying two stocks of $B$. b. gracilis. Digenea L. retroflexus, A. laguncula and Anisakid larvae were the most important species in determining the position of sampled fishes from the central coast off Tunisia. Metacercaria $C$. pilodora characterized specimens from the Southern coast off Tunisia. These results were corroborated by comparing parameters of prevalence and mean abundance between zones. Discriminant analysis used for the separation of $B$. b. gracilis between seasons in both localities showed that a seasonal variation affected mainly specimens from the center suggesting seasonal move of fishes.

\section{Keywords}

Belone belone gracilis, Metazoan Parasites, Stock Discrimination, Tunisian Coast, Mediterranean Sea

\footnotetext{
"Corresponding author.
}

How to cite this paper: Châari, M., Feki, M. and Neifar, L. (2015) Metazoan Parasites of the Mediterranean Garfish Belone belone gracilis (Teleostei: Belonidae) as a Tool for Stock Discrimination. Open Journal of Marine Science, 5, 324-334. 


\section{Introduction}

Garfish, Belone belone (Linnaeus, 1761) is an epipelagic teleost marine fish widely distributed in the northeastern Atlantic Ocean, the Mediterranean and the Black Sea. Three subspecies have been recognised according to their geographic distribution: B. b. belone (Linnaeus, 1761) restricted to the north-eastern Atlantic; B. b. euxini Günther, 1866 founded in the Black Sea and B. b. gracilis Lowe, 1839 mainly distributed in the Mediterranean Sea [1].

Parasite fauna of Belone belone has received considerable taxonomic interest. Nine metazoan parasite species have been therefore reported in the Mediterranean subspecies B. b. gracilis [2]-[11]. Recently Radujković and Šundić (2014) listed six flatworm’s species in the Adriatic Sea [12]. Oktener (2005) and Keser et al. (2007) recorded two species of parasites in the Black sea subspecies B. b. euxeni [13] [14]. Rynkiewicz (1970) and Grabda (1981) signalized eleven metazoan parasite species in the north east Atlantic subspecies B. b. belone and a geographic variation of its parasites were also shown by Grabda (1981) [15] [16].

At regional scale, parasite composition of $B$. $b$. gracilis remains unknown in the southern shore of the Mediterranean Sea; most studies on the metazoan parasites of B. b. gracilis were carried out in the north western and central Mediterranean Sea. Understanding geographical variation in the composition, abundance and diversity of parasite is important to identify and delineate populations of fish species in different regions of the world [17]-[20]. Therefore, in this study we try to list for the first time regionally the parasite fauna of B. b. gracilis in the south western Mediterranean Sea. Secondly, at local scale we use spatial variability of parasites between the central and southern coast off Tunisia for eventual identification of different stocks. Thus, parasites can be used as a model for the discrimination of fish stocks. It's well known that parasites have been used as biological tags in the stock discreteness, migratory movements of marine fish as well as indicators of host phylogenetics and systematics [21]-[27].

Knowledge of the number of fish stocks of $B$. $b$. gracilis is a basic requirement to ensure sustainable fishing. Indeed, overexploitation of benthic fish stock [28], currently in danger [29] (Anonymous, 2002), led to other little or no exploited resources. These resources are mainly the stock of small pelagic fishes and secondary economic interest fishes such belonid fishes. In eastern Tunisian coast, belonids landings represent only $0.3 \%$ of the national production in 2010 which province from fishing area at the central and the southern zones (almost 90\%) [30].

The aims of this paper were to identify the metazoan parasites of $B$. $b$. gracilis in the south western Mediterranean Sea and to assess using spatial and temporal variability of metazoan parasites at local scale for stocks discrimination.

\section{Materials and Methods}

\subsection{Study Area and Examination of Samples}

A total of 453 specimens of Belone belone gracilis were randomly sampled from local fishermen using gillnets in common fishing areas off eastern Tunisian coast: the central zone (Gulf of Hammamett) and the southern zone (Gulf of Gabes) (Table 1).

Fishes were identified using Bauchot (1987) [31]. Sampled fishes fresh and frozen were subsequently examined for ecto- and endoparasites. Parasitological examination using a stereomicroscope under incident light included the skin, fins, gills, eyes, body cavity and visceral organs (stomach, intestine, liver, the pericardial cavity, swimbladder, gallbladder and gonads). Platyhelminthes were fixed between slide and coverslip in 70\% al-

Table 1. The number of samples of Belone belone gracilis caught from two zones off the eastern coast of Tunisia (NT: total number, TL: total length of fish samples).

\begin{tabular}{cccccccc}
\hline \multirow{2}{*}{ Locality } & \multicolumn{2}{c}{ Season } & & NT & TL (cm) \\
\cline { 2 - 8 } & Autumn & winter & Spring & Summer & & \\
\hline Centre & 59 & 19 & 48 & 79 & 205 & $24.3-55$ \\
South & 36 & 22 & 98 & 92 & 248 & $24.2-53.7$ \\
\hline
\end{tabular}


cohol or in Bouin's fluid. Fixed specimens were stained with Semichon's acetic carmine, dehydrated using a graded ethanol series then cleared in clove oil and mounted in Canada balsam. Other parasites (copepod, isopod, nematod and acanthocephalan) were directly fixed in $70 \%$ for later examination. Parasites were determined to the lowest taxonomic level possible.

\subsection{Data Analysis}

Prevalence (P) and mean abundance (MA) were determined following Bush et al. (1997) [32]. Non parametric analyses were performed to evaluate characteristics of the infection at population and community levels. Univariate analysis was performed to evaluate the infections at infrapopulation levels only for parasites with prevalence $>5 \%$ [32]. $\chi^{2}$ analyses and a posteriori multiple comparisons for proportions were used to test for significant differences of prevalence between zones [33]. Student test was used to examine effect of geographic variation on mean abundance of parasites after $\log 10(x+1)$ transformed data.

Discriminant analyses, based on Mahalanobis distances were used to find differences between zones and between seasons in both zones (eight groups: every season associated to every locality) and to identify which parasite species were responsible for these differences [34].

\section{Results}

A total of 395 (87\%) fish was found to be parasitized by at least one of parasite species. There were 12434 specimens of metazoan parasites collected, with mean of $32 \pm 53$ parasite/fish $(1$ - 408). Ten parasite species were identified: one monogenean Axine belones Abildgaard, 1794; four digenans Lecithostaphylus retroflexus (Molin, 1859), Tergestia acanthocephala (Stossich, 1887) Stossich, 1899, Aponurus laguncula Looss, 1907 and Condylocotyla pilodora metacercaria Pearson et Prévot, 1985; one nematod Anisakid larvae; one acanthocephalan Telosentis exiguus (Von Linstow, 1901); one copepod Bomolochus bellones Burmeister, 1835 and two isopods Irona nana Schioedte et Meinert, 1884 and Nerocila orbignyi (Guérin-Méneville, 1832) (Table 2). Infection site, prevalence and mean abundance of parasite species were also shown in Table 2. Digenean parasites were the most abundant and accounted $85 \%$ of collected material (Figure 1). Condylocotyla pilodora was the most abundant species with 9661 specimens collected (77.69\% of all parasites). Only common parasites with prevalence $>5 \%$ in at least one station were included in further analyses as recommended by Bush et al. (1997).

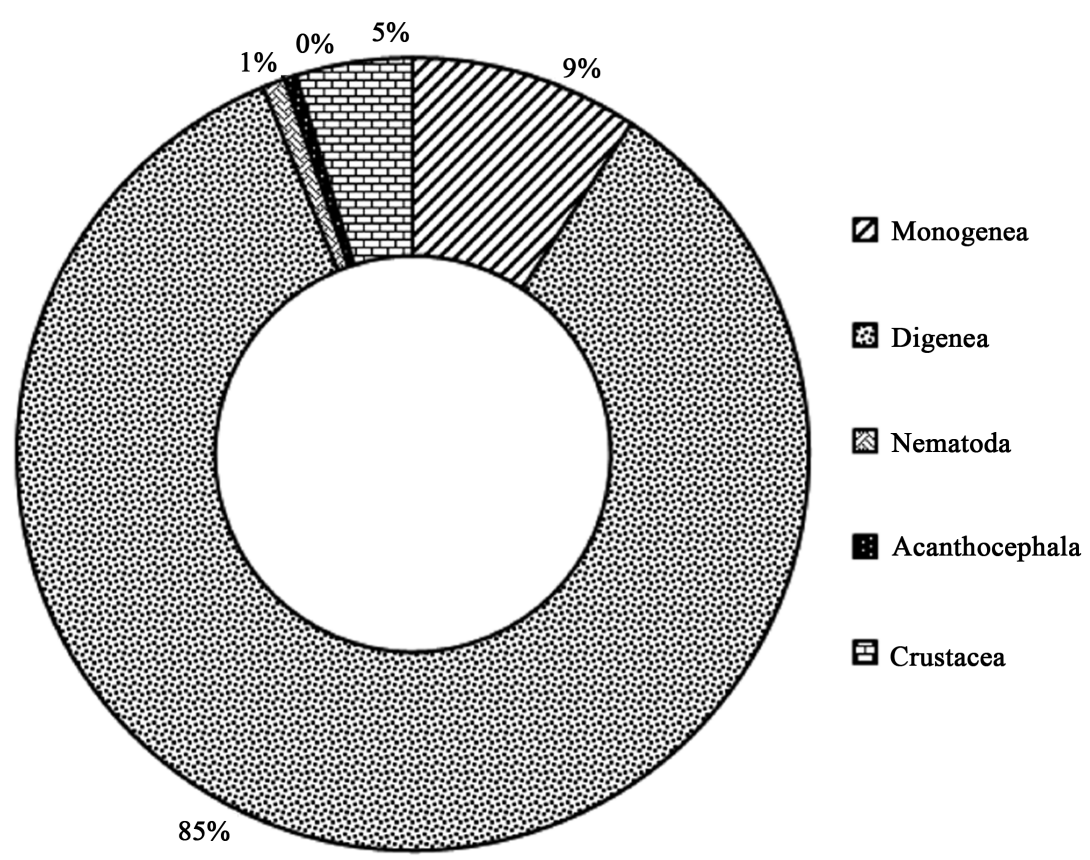

Figure 1. Participation of particular taxons of metazoan parasites in B. b. gracilis off Tunisian coast. 
Table 2. Prevalence, mean abundance and infection site of the metazoan parasites of Belone belone gracilis. SI: site of infection, P: prevalence and MA: mean abundance, DT: digestive tract, G: gills, L: liver, PS: Pericardial sac, Fi: Fins.

\begin{tabular}{|c|c|c|c|}
\hline Parasite & SI & $\mathbf{P} \%$ & MA \\
\hline \multicolumn{4}{|l|}{ Monogenea } \\
\hline Axine belones & G & 59 & 2.57 \\
\hline \multicolumn{4}{|l|}{ Digenea } \\
\hline Condylocotyla pilodora (metacercria) & PS, DT & 50 & 21.42 \\
\hline Lecithostaphylus retroflexus & DT & 11 & 0.21 \\
\hline Tergestia acanthocephala & DT & 24 & 1.17 \\
\hline Aponurus laguncula & DT & 12 & 0.5 \\
\hline \multicolumn{4}{|l|}{ Crustacea } \\
\hline \multicolumn{4}{|l|}{ Copepoda } \\
\hline Bomolochus bellones & G & 42 & 1.23 \\
\hline \multicolumn{4}{|l|}{ Isopoda } \\
\hline Irona nana & G & 7 & 0.07 \\
\hline Nerocila orbygini & $\mathrm{Fi}$ & 1 & 0.01 \\
\hline \multicolumn{4}{|l|}{ Acanthocephala } \\
\hline Telosentis exiguus & DT & 4 & 0.13 \\
\hline \multicolumn{4}{|l|}{ Nematoda } \\
\hline Anisakid larvae & DT, L & 9 & 0.26 \\
\hline
\end{tabular}

\subsection{Geographic Variation}

Comparisons of prevalence and mean abundance showed that five parasites differ significantly between two sampled zones. A. laguncula and L. retroflexus were more prevalent and abundant in the central zone. Anisakid larvae were more abundant in the center. C. pilodora and T. exiguus were more abundant in the southern zone (Table 3).

A multivariate analysis used for the separation of $B$. b. gracilis between localities showed that the first discriminant functions explained $100 \%$ of the variance (eigenvalue $=0.120$ ). There was a significant overall effect of group (Wilks' lambda $=0.893, \mathrm{~F}_{446} ; p<0.01$ ). Individual fishes were distributed mainly along the first axe. Using dimensionality tests showed that the two studied zones were significantly separated in both dimensions $\left(\chi^{2}=50.676\right.$, d.f. $\left.=4, p<0.01\right)$. Each fish was classified correctly to the two component communities with an accuracy of $64.3 \%$ (Table 4). Scores of individual fishes showed a clear discrimination between two groups, one including fishes from the center and one including specimens from the south. The importance of each parasite species with respect to discrimination between groups, evaluated as the contribution of each variable to the total sum Mahalanobis distances, showed that Digenea L. retroflexus, A. laguncula and Nematoda Anisakid larvae were the most important species in determining the position of samples from the central zone. Metacercaria $C$. pilodora was characteristic of specimens from the south.

\subsection{Seasonal Variation}

A multivariate analysis used for the separation of $B$. b. gracilis between seasons in both localities showed that the first two discriminant functions explained $79.8 \%$ of the variance, contributing to $51.4 \%$ (eigenvalue $=0.448$ ) and $28.4 .3 \%$ (eigenvalue $=0.247$ ), respectively. There was a significant difference between groups (Wilks' lambda $=0.467 ; \mathrm{F}_{8.408} ; p<0.01$ ) (Figure 2(a)). Dimensionality tests showed that seasons were significantly separated in both dimensions $\left(\chi^{2}=328.482\right.$, d.f $\left.=42, p<0.01\right)$. Results showed a clear discrimination between 


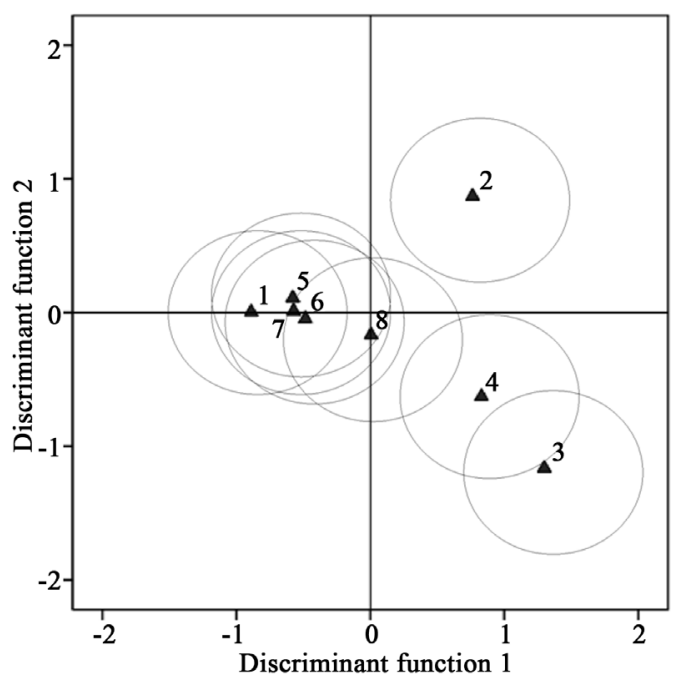

(a)

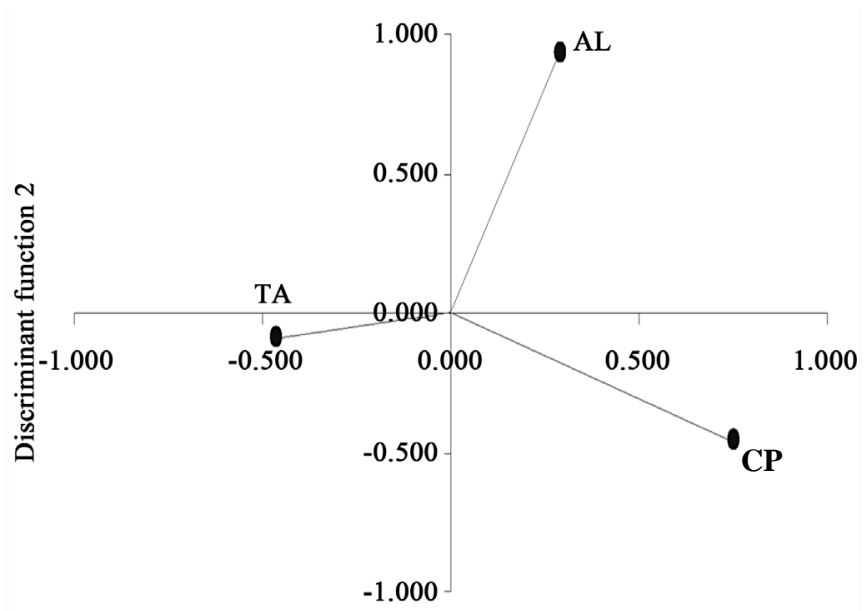

Discriminant function 1

(b)

Figure 2. (a) Sample scores of the first two discriminant functions for specimens of B. b. gracilis from center and south/ seasons: 1, samples from center in Autumn; 2, samples from center in summer; 3, samples from center in winter, 4 samples from center in spring; 5, samples from south in Autumn; 6, samples from south in summer; 7, samples from south in winter; 8, samples from south in spring. Lettering on the axes represent groups averages surrounded by circles $90 \%$ to show tolerances; (b) canonical correlations between the first tow discriminant functions and three parasites species between zone/seasons; Aponurus laguncula (AL), Tergestia acanthocephala (TA) and Condylocotyla pilodora (CP).

Table 3. Comparison of prevalence and mean abundance of selected metazoan parasites from B. b. gracilis among two zones in eastern Tunisian Coast.

\begin{tabular}{ccccccccccc}
\hline & \multicolumn{4}{c}{ Prevalence } & \multicolumn{5}{c}{ Mean abundance } \\
& Center & South & $\chi^{2}$ & $\boldsymbol{p}$ & Center & South & t & $\boldsymbol{p}$ \\
\hline Axine belones & 61 & 58 & 0.07 & 0.79 & 2.65 & 2.50 & 0.83 & 0.40 \\
Condylocotyla pilodora (metacercaria) & 56 & 46 & 0.92 & 0.34 & 0.76 & 1.50 & 4.32 & $0.00^{*}$ \\
Lecithostaphylus retroflexus & 19 & 4 & 8.63 & $0.00^{*}$ & 0.35 & 0.08 & 4.84 & $0.00^{*}$ \\
Tergestia acanthocephala & 20 & 27 & 0.88 & 0.35 & 0.87 & 0.19 & -1.56 & 0.11 \\
Aponurus laguncula & 20 & 5 & 7.82 & $0.01^{*}$ & 34.70 & 10.48 & 4.97 & $0.00^{*}$ \\
Bomolochus bellones & 7 & 7 & 0.00 & 0.95 & 0.36 & 0.24 & 0.86 & 0.38 \\
$\quad$ Irona nana & 5 & 9 & 0.64 & 0.42 & 0.08 & 0.40 & -1.72 & 0.08 \\
Telosentis exiguus & 6 & 1 & 2.32 & 0.12 & 0.05 & 0.10 & 2.30 & $0.02^{*}$ \\
Anisakid larvae & 5 & 12 & 1.86 & 0.16 & 0.19 & 0.07 & -2.60 & $0.01^{*}$ \\
\hline
\end{tabular}

Table 4. Discriminant analysis classifications showing the numbers and percentages of fish classified in each zone (rows correspond to group memberships).

\begin{tabular}{cccc} 
& Center & South & Per cent \\
\hline Center & 96 & 107 & $52.7 \%$ \\
South & 54 & 194 & $78.2 \%$ \\
\hline
\end{tabular}

three groups. One including fishes from the south in all seasons and fishes from the center in autumn, one including those from the center in winter and spring and one including samples from the center in summer. $T$. acanthocephala was the most important species in determining samples from the first group. C. pilodora was 
the most important species identifying specimens of winter and spring from the second group. A. laguncula characterized specimens from the third group (Figure 2(b)).

\section{Discussion}

The present study increases our knowledge on the metazoan parasite of the Mediterranean subspecies $B$. $b$. gracilis. This is the first survey on the entire parasite fauna of B. b. gracilis from southern shore of the Mediterranean Sea. Previous records of parasites from B. $b$. gracilis come from taxonomic studies of individual parasite species such as cestod Ptychobothrium belones; copepod B. bellones; digeneans L. retroflexus, T. acanthocephala, A. laguncula and C. pilodora metacercaria; isopods I. nana; monogenean A. belones and acanthocephalan T. exiguus [2]-[11]. In the central Mediterranean Sea, Radujković and Šundić (2014) listed six parasite species on B. b. gracilis (Table 5). In our study, remaining parasite species excepting cestod were found on $B . b$.

Table 5. Comparaison of parasitism of B. belone subspecies.

\begin{tabular}{|c|c|c|c|c|c|c|}
\hline Host & \multicolumn{2}{|c|}{ Belone belone gracilis } & \multicolumn{3}{|c|}{ Belone belone belone } & \multirow{2}{*}{$\begin{array}{c}\text { Belone } \\
\text { belone euxeni }\end{array}$} \\
\hline Locality & Adriatic Sea & Tunisian coast & Baltic sea & Southern Baltic sea & $\begin{array}{l}\text { Courtmacsherry } \\
\text { Bay, Co Cork, } \\
\text { Ireland }\end{array}$ & \\
\hline Parasites/author & $\begin{array}{l}\text { Radujković and } \\
\text { Sundić (2014) }\end{array}$ & Present study & Rynkiewicz (1970) & Grabda (1981) & Dorman (1991) & $\begin{array}{c}\text { Oktener (2005), } \\
\text { Keser } \\
\text { et al. (2007) }\end{array}$ \\
\hline Monogenea & Axine belones & Axine belones & - & - & - & Axine belones \\
\hline \multirow[t]{4}{*}{ Digenea } & - & $\begin{array}{c}\text { Condylocotyla } \\
\text { pilodora }\end{array}$ & $\begin{array}{l}\text { Diplostomum } \\
\text { spathaceum }\end{array}$ & - & - & $\begin{array}{l}\text { Lecithostaphylus } \\
\text { retroflexus }\end{array}$ \\
\hline & $\begin{array}{l}\text { Lecithostaphylus } \\
\text { retroflexus }\end{array}$ & $\begin{array}{l}\text { Lecithostaphylus } \\
\text { retroflexus }\end{array}$ & Tylodelphys sp. & - & - & - \\
\hline & $\begin{array}{c}\text { Theledera } \\
\text { acanthocephala }\end{array}$ & $\begin{array}{c}\text { Tergestia } \\
\text { acanthocephala }\end{array}$ & & - & - & - \\
\hline & $\begin{array}{l}\text { Aponurus } \\
\text { laguncula }\end{array}$ & $\begin{array}{l}\text { Aponurus } \\
\text { laguncula }\end{array}$ & & - & - & - \\
\hline \multirow[t]{2}{*}{ Cestoda } & $\begin{array}{l}\text { Lacistorhynchus } \\
\text { tenuis }\end{array}$ & - & $\begin{array}{c}\text { Scolex } \\
\text { pleuronectis }\end{array}$ & $\begin{array}{c}\text { Lacistorhynchus } \\
\text { tenuis }\end{array}$ & - & - \\
\hline & $\begin{array}{l}\text { Ptychobothrium } \\
\text { belones }\end{array}$ & - & - & - & - & - \\
\hline \multirow[t]{3}{*}{ Copepoda } & - & $\begin{array}{c}\text { Bomolochus } \\
\text { bellones }\end{array}$ & - & - & Caligus belones & - \\
\hline & - & & - & - & Caligus elongatus & - \\
\hline & & & & & Caligus pelamydis & - \\
\hline \multirow[t]{2}{*}{ Isopoda } & - & Irona nana & - & - & Nerocila orbygini & - \\
\hline & - & Nerocila orbygini & - & - & - & - \\
\hline \multirow[t]{3}{*}{ Acanthocephala } & - & Telosentis exiguus & $\begin{array}{c}\text { Pomphorynchus } \\
\text { laevis }\end{array}$ & $\begin{array}{c}\text { Pomphorynchus } \\
\text { laevis }\end{array}$ & - & - \\
\hline & - & - & $\begin{array}{c}\text { Neoechinorhynchus } \\
\text { rutili }\end{array}$ & $\begin{array}{l}\text { Neoechinorhynchus } \\
\text { rutili }\end{array}$ & - & - \\
\hline & - & - & - & $\begin{array}{c}\text { Echinorhynchus } \\
\text { gadi }\end{array}$ & - & - \\
\hline \multirow[t]{2}{*}{ Nematoda } & - & Hysterotylacium sp. & $\begin{array}{c}\text { Contracaecum } \\
\text { aduncum }\end{array}$ & Anisakis simplex & - & - \\
\hline & - & Contracaecum sp. & $\begin{array}{c}\text { Cuculanus } \\
\text { truttae }\end{array}$ & $\begin{array}{l}\text { Thynnascaris } \\
\text { adunca }\end{array}$ & - & - \\
\hline
\end{tabular}


gracilis alongside specimens of nematod Anisakid larvae and isopod $N$. orbignyi. Latest species have been reported from B. b. belone in the north east Atlantic by Dorman (1991) [35], but not found previously in Belonids from Tunisian coast. $N$. orbignyi was collected attached mainly to fins of Mugilids, rarely on Solea solea Linnaeus, 1758 and Dicentrarchus labrax Linnaeus, 1758 [9]. The low value of prevalence of N. orbignyi (1\%) compared to that reported by Cheikhrouha et al. (2000) in Mugilids (47\%) calls for an accidental infestation.

A comparison of the parasite fauna composition of B. b. gracilis with those of B. $b$. euxeni revealed similarity between parasite species of the Mediterranean and the Black Sea subspecies of $B$. belone (Table 5). Indeed, $B$. $b$. euxeni from the Black Sea hosted A. belones and L. retroflexus [13] [14]. These parasite species could be with a wide distribution, present in the Mediterranean and the Black Seas. Nevertheless, the metazoan parasite fauna of B. b. gracilis was totally different from that reported on B. b. belone in the north east Atlantic [15] [16]. Indeed, ten parasites taxa can be identified as proper to the Mediterranean Sea subspecies B. b. gracilis and seven parasites taxa can be identified as proper to the Atlantic subspecies $B$. $b$. belone were founded. It appears that variation in infection with parasites on $B$. belone could be influenced by geographical distribution of these different subspecies of hosts or by specificity of parasites in the host subspecies. B. b. gracilis, B. b. euxeni and B. b. belone are recognized by Collette (2003) as different subspecies that lives in completely different and separate ecosystems [1]. More detailed studies involving the qualitative and the quantitative aspect of the metazoan parasites of $B$. $b$. euxeni are necessary for providing useful information on the use of parasites for separating subspecies of $B$. belone. These results could reinforce the usefulness of parasites as adequate tools to clarify the taxonomic status of their hosts. In fact, parasites have been used successfully not only as tools to understand the population structure of the host species but also to clarify doubtful systematic relations between closely related hosts [36]. In this context, Oliva and Ballon (2002) evaluated also the use of metazoan parasites of the hake, Merlucciuus gayii (Guichenot, 1848) as biological tags for stocks identification of fish subspecies [37]. Indeed, result of examined specimens of Chilean hake subspecies Merluccius gayi gayi (Guichenot, 1848) in the central and southern Chile as well as analysis of previously published data on Peruvian hake subspecies Merluccius gayi peruanus (Guichenot, 1848) from Peru revealed presence of 12 species found only in the Chilean hake and seven species exclusively found in the Peruvian hake. Thus, differences in infection with parasite can be due to the geographic distribution of the host; phylogeny and also to variation of biological and ecological factors [38]-[42]. These factors can act individually or together altering the parasite distribution patterns in their hosts [43].

Our findings showed that Digenea were the most abundant parasites in the viewpoint of species richness (number of parasites species) and number of individuals collected from $B$. $b$. gracilis. Diversity of digenean parasites appears to be an index of the diversity of intermediate hosts ingested and therefore a varied diet of the host. Garfish B. belone is carnivorous based mainly on crustaceans (brachyura, copepod and decapod), followed by teleost fish and other items of terrestrial origin, including insects [44] [45]. Indeed, piscivorous fish occupy the top of the food web and may present more chance of infection [46]. Among digenean parasites, metacercaria Condylocotyla pilodora is the most abundant species found on B. b. gracilis. The high infection with C. pilodora could be explained by the long life of encysted parasites which may be longer than those of intestinal parasites. Indeed, encysted parasites, mainly in muscles and abdominal cavity cannot be released from the host and are therefore accumulated in the organism [47]. The Shoaling behaviour and the pelagic mode of life of this Belonids could also explain the success of $C$. pilodora to reach its definitive host. The life-cycle of $C$. pilodora involves the first intermeditae host a snail Cerithium vulgatum Bruguière, 1792, the metacercariae in the pericardial sac of the second intermediate hosts a fish Belone belone, and adults in the definitive host a herring gull Larus argentatus [7].

Nine species of parasites among ten, reaching a prevalence $>5 \%$ in at least one of the studied zones, were selected as biological tags. The significant differences of both infection parameters prevalence and mean abundance between areas and results of discriminant analysis demonstrate the potential value of selected parasites as biological tags. Two stocks can be identified, one in the central and one in the southern Tunisian coast.

Distribution patterns of parasites showed difference between fishes from the central zone and those from the southern zone. Indeed, specimens of $B$. $b$. gracilis from the center were characterized by the highest abundance of Adult Digenea A. laguncula and L. retroflexus. Whereas, specimens from the southern coast off Tunisia were characterized by the highest abundance of Digenea metacercaria C. pilodora. It appears that central coast of Tunisia is probably the endemic area of the first intermediate host (mollusc) of A. laguncula and L. retroflexus but in the southern coast environmental conditions can be more suitable for transmission of the first intermediate 
host of the digenean metacercaria C. pilodora which is the snail Cerithium vulgatum that prefers areas of low wave intensity [48]. This could reflect the different oceanographic characteristics of both ecosystems. Central coast off Tunisia (Gulf of Hammamet) is characterized by the existence of a relatively strong and continuous current (Atlantic), which would be added to littoral currents and combined to currents generated by the wind [49]; whereas in the southern coast (Gulf of Gabes) characterized by the extended continental shelf, the Atlantic current losing influence due to the presence of local permanent cyclonic circulation and hydrodynamics generally under the control of winds in deep areas and tidal along the coastline [50]-[52].

Specimens of $B$. $b$. gracilis from the central coast were characterized by the highest abundance of Nematod Anisakid larvae. This difference could be related to quantitative and qualitative change of the diet of B. b. gracilis between the center and the south off Tunisia and therefore variation in the intermediate host's involved. Transmission pathways of ascaridoid Nematoda are habitat-dependent and usually involve a broad spectrum of invertebrates and intermediate or paratenic fish hosts [53]. Several larval stages could therefore be affected differentially by environment factors [54]. The paucity of Anisakid larvae in the south may be also a consequence of the unstable environment due to the pollution by various industrial and urban activities in the Gulf of Gabes which disrupts the stability of the ecosystem. The damage of this ecosystem can generate consequently a variation of the intermediate host's distribution (invertebrates, fish).

These results were corroborated by those of discriminant analysis which showed that fishes from the two areas represented two units with a mean accuracy of correctly classifying fishes to their respective zone (64.3\%). Fishes from the south were more classified in their origin area with an accuracy of (78.2\%) than fishes from the centre (52.7\%). This is the result of distance separating samples, a common phenomenon that usually emerges as the best predictor of similarity in the analyses of parasites communities in relation to characteristics of the habitat [55] [56]. Results of geographic variation can be confirmed by those from discriminant analysis of seasonal variation in both localities. Indeed, specimens from the south were clumped together as a single stock. Fishes from the center were separated in three groups according to seasons where Digenea T. acanthocephala and A. laguncula were the most responsible for these differences. Seasonal variation of Digenea with short life span could be explained by the seasonal variation of the host's diet. The change in the diet composition may be associated with ecological characters of hosts such as feeding behavior and seasonal changes [47]. Additionally, seasonal variability of the distribution of the fish hosts can be related to the seasonal variation of the activity of the fishing fleets. The accuracy of classifying fishes incorrectly in their origin zone can be explained by migratory movements of $B$. $b$. gracilis between inshore and offshore waters in search of optimal conditions for living, feeding and breeding. Parasites can be also used to follow seasonal migrations of fish to and from spawning and feeding grounds [57]. In the Baltic Sea, parasites have been successfully used by Grabda (1981) for stock discrimination of the garfish B. belone. B. belone spawn in areas of low salinity and migrate seasonally to feeding grounds farther west in areas of higher salinity. These migratory stocks can be identified on the spawning grounds by their infections of the characteristically marine anisakid nematode larvae, adult hemiurid digeneans and trypanorynch metacestodes.

\section{Conclusion}

In summary, a complete list of metazoan parasites of B. $b$. gracilis from Tunisian coast was established for the first time. Findings of different parasite taxa in the Mediterranean subspecies B. $b$. gracilis compared to those of the Atlantic subspecies B. b. belone could reinforce the usefulness of parasites as adequate tools to clarify the taxonomic status of their hosts. Studies of spatial and seasonal variability of metazoan parasites in the garfish $B$. b. gracilis off Tunisia allowed for the identification of discrete stocks in the central coast characterized by Nematoda Anisakid larvae and in the southern coast characterized by digenean metacercaria Condylocoltyla pilodora.

\section{References}

[1] Collette, B.B. (2003) Family Belonidae (Bonaparte, 1832) Needlefish. Annotated Checklist of Fish. California Academy of Sciences, 16, 22 p.

[2] Dujardin, F. (1845) Histoire naturelle des Helminthes ou Vers intestinaux. Librairie encyclopedique de Roret, Paris, 654 pp. http://dx.doi.org/10.5962/bhl.title.10123

[3] Timon-David, J. (1937) Etude sur les trématodes parasites des poissons du golfe de Marseille. Bulletin de l'Institut 
Océanographique de Monaco, 717, 1-24.

[4] Vervoort, W. (1962) A Review of the Genera and Species of the Bomolochidae (Crustacea, Copepoda), Including the Description of Some Old and New Species. Zoologische Verhandelingen, 56, 1-111.

[5] Trilles, J.P. and Raibaut, A. (1971) Aegidae et Cymothoidae parasites de poissons de mer Tunisienne. Premiers résultats. Bulletin national d'océanographie et de pêche Salammbô, 2, 71-86.

[6] Euzet, L. and Lopez-Roman, R. (1973) Nuevos datos sobre la morfologia y la anatomia de Axine belones Abildgaard, 1794 (Monogenea). Revista Iberica de Parasitologia, 33, 557-571.

[7] Pearson, J.C. and Prévot, G. (1985) A Revision of the Subfamily Haplorchinae Looss, 1899 (Trematoda: Heterophyidae). III-Genera Cercarioides and Condylocotyla n.g. Systematic Parasitology, 7, 169-197. http://dx.doi.org/10.1007/BF00011450

[8] Bray, R.A. and Mackenzie, K. (1990) Aponurus laguncula Looss, 1907 (Digenea: Lecithasteridae): A Report from Herring, Clupea harengus L., in the Eastern English Channel and a Review of Its Biology. Systematic Parasitology, 15, 117-124. http://dx.doi.org/10.1007/bf00009799

[9] Cheikhrouha, C.F., Zghidi, W., Ould Yarba, L. and Trilles, J.P. (2000) Les Cymothoidae (Isopodes parasites de poissons) des côtes tunisiennes: Ecologie et indices parasitologiques. Systematic Parasitology, 46, 143-150. http://dx.doi.org/10.1023/A:1006336516776

[10] Bartoli, P., Bray, R.A. and Gibson, D.I. (2003) Lecithostaphylus retroflexus (Molin, 1859) (Zoogonidae) and Tergestia acanthocephala (Stossich, 1887) (Fellodistomidae) (Digenea) from the Epipelagic Teleost Belone belone (L.) in the Western Mediterranean. Systematic Parasitology, 54, 131-143. http://dx.doi.org/10.1023/A:1022549222774

[11] Kvach, Y. and Sasal, P. (2010) Telosentis exiguus (von Linstow, 1901) (Palaeacanthocephala: Illiosentidae), a Generalist Parasite of Fishes in the Mediterranean Basin. Systematic Parasitology, 76, 9-18. http://dx.doi.org/10.1007/s11230-009-9222-6

[12] Radujković, B.M. and Šundić, D. (2014) Parasitic Flatworms (Platyhelminthes: Monogenea, Digenea, Cestoda) of Fishes from the Adriatic Sea. Natura Montenegrina, 13, 7-280.

[13] Oktener, A. (2005) A Checklist of Parasitic Helminths Reported from Sixty-Five Species of Marine Fish from Turkey Including Two New Records of Monogeneans. Zootaxa, 1063, 33-52.

[14] Keser, R., Bray, R.A., Oğuz, M.C., Çelen, S., Erdoğan, S., Doğutürk, S., Aklanoğlu, G. and Marti, B. (2007) Helminth Parasites of Digestive Tract of Some Teleost Fish Caught in the Dardanelles at Çanakkale, Turkey. Helminthologia, 44, 217-221. http://dx.doi.org/10.2478/s11687-007-0035-3

[15] Rynkiewicz, J. (1970) The Parasite Fauna of Garfish Belone belone (L.) from Puck Bay. Acta Ichthyologica et Piscatoria, 1, 103-106.

[16] Grabda, J. (1981) Parasitic Fauna of Garfish Belone belone (L.) from the Pomeramian Bay (Southern Baltic) and Its Origin. Acta Ichthyologica et Piscatoria, 11, 75-85.

[17] Luque, J.L. and Poulin, R. (2007) Metazoan Parasite Species Richness in Neotropical Fishes: Hotspots and the Geography of Biodiversity. Parasitology, 134, 865-878. http://dx.doi.org/10.1017/S0031182007002272

[18] Poulin, R. (2007) The Structure of Parasite Communities in Fish Hosts: Ecology Meets Geography and Climate. Parassitologia, 49, 169-172.

[19] Timi, J.T., Lanfranchi, A.L. and Luque, J.L. (2010) Similarity in Parasite Communities of the Teleost Fish Pinguipes brasilianus in the Southwestern Atlantic: Infracommunities as a Tool to Detect Geographical Patterns. International Journal for Parasitology, 40, 243-254. http://dx.doi.org/10.1016/j.ijpara.2009.07.006

[20] Braicovich, P.E., Luque, J.L. and Timi, J.T. (2012) Geographical Patterns of Parasite Infracommunities in the Rough Scad, Trachurus Lathami Nichols, in the Southwestern Atlantic Ocean. Journal of Parasitology, 98, 768-777. http://dx.doi.org/10.1645/GE-2950.1

[21] Williams, H.H., MacKenzie, K. and McCarthy, A.M. (1992) Parasites as Biological Indicators of the Population Biology, Migrations, Diet, and Phylogenetics of Fish. Reviews in Fish Biology and Fisheries, 2, 144-176. http://dx.doi.org/10.1007/BF00042882

[22] MacKenzie, K. and Abaunza, P. (1998) Parasites as Biological Tags for Stock Discrimination of Marine Fish: A Guide to Procedures and Methods. Fisheries Research, 38, 45-56. http://dx.doi.org/10.1016/S0165-7836(98)00116-7

[23] MacKenzie, K. (2002) Parasites as Biological Tags in Population Studies of Marine Organisms: An Update. Parasitology, 124, 153-163. http://dx.doi.org/10.1017/S0031182002001518

[24] George-Nascimento, M. (2000) Geographical Variations in the Jack Mackerel Trachurus symmetricus murphyi Populations in the Southeastern Pacific Ocean as Evidenced from the Associated Parasite Communities. Journal of Parasitology, 86, 929-932. http://dx.doi.org/10.1645/0022-3395(2000)086[0929:GVITJM]2.0.CO;2 
[25] Oliva, M.E. (2001) Metazoan Parasites of Macruronus magellanicus from Southern Chile as Biological Tags. Journal of Fish Biology, 58, 1617-1624. http://dx.doi.org/10.1111/j.1095-8649.2001.tb02316.x

[26] Timi, J.T. (2003) Parasites of Argentine Anchovy in the Southwest Atlantic: Latitudinal Patterns and Their Use for Discrimination of Host Populations. Journal of Fish Biology, 63, 90-107. http://dx.doi.org/10.1046/j.1095-8649.2003.00131.x

[27] MacKenzie, K. and Abaunza, P. (2005) Parasites as Biological Tags. In: Cadrin, S.X., Friedland, K.D. and Waldman, J.R., Eds., Stock Identification Methods: Applications in Fisheries Science, Elsevier, San Diego, 211-226. http://dx.doi.org/10.1016/B978-012154351-8/50012-5

[28] Jarboui, O., Ghorbel, M. and Bouain, A. (1998) Le stock du pageot commun Pagellus erythrinus du golfe de Gabès (Tunisie): Etat d'exploitation et possibilités d’aménagement. Cahier Options Mediterranéenne, 35, 251-260.

[29] Anonymous (2002) Rapport national sur la biodiversité marine et côtière en Tunisie. Institut National Agronomique de Tunisie.

[30] Anonymous (2010) Annuaires statistiques des produits de la pêche en Tunisie. Direction Générale de la pêche et de l'aquaculture.

[31] Bauchot, M.L. (1987) Méditerranée et mer Noire. Zone de pêche 37. In: Fisher, W., Bauchot, M.L. and Scheinder, M., Eds., Fiches FAO d'Identification des Espèces pour les Besoins de la Pêche, Vertébrés, Vol. 2, FAO, Rome, 976-980.

[32] Bush, A.O., Lafferty, K.D., Lotz, J.M. and Shostak, A.W. (1997) Parasitology Meets Ecology on Its Own Terms: Margolis et al. Revisited. Journal of Parasitology, 83, 575-583. http://dx.doi.org/10.2307/3284227

[33] Zar, J.H. (1996) Biostatistical Analysis. 3rd Edition, Prentice-Hall, Upper Saddle River.

[34] Brodgar (2000) Software Package for Multivariate Analysis and Multivariate Time Series Analysis. Highland Statistics Ltd., Aberdeen.

[35] Dorman, J.A. (1991) Investigations onto the Biology of the Garfish, Belone belone (L.), in Swedish Waters. Journal of Fish Biology, 39, 59-69. http://dx.doi.org/10.1111/j.1095-8649.1991.tb04341.x

[36] Oliva, M.E., Valdivia, I.M., Costa, G., Freitas, N., Pinheiro de Carvalho, M.A., Sanchez, Z.L. and Luque, J.L. (2008) What Can Metazoan Parasites Reveal about the Taxonomy of Scomber japonicus Houttuyn in the Coast of South America and Madeira Islands. Journal of Fish Biology, 72, 545-554. http://dx.doi.org/10.1111/j.1095-8649.2007.01725.x

[37] Oliva, M.E. and Ballon, I. (2002) Metazoan Parasites of the Chilean Hake Merluccius gayi gayi as a Tool for Stock Discrimination. Fisheries Research, 56, 313-320. http://dx.doi.org/10.1016/S0165-7836(01)00329-0

[38] Poulin, R. (1995) “Adaptive” Changes in the Behaviour of Parasitized Animals: A Critical Review. International Journal for Parasitology, 25, 1371-1383. http://dx.doi.org/10.1016/0020-7519(95)00100-X

[39] Sepúlveda, F., Marín, S. and Carvajal, J. (2004) Metazoan Parasites in Wild Fish and Farmed Salmon from Aquaculture Sites in Southern Chile. Aquaculture, 235, 89-100. http://dx.doi.org/10.1016/j.aquaculture.2003.09.015

[40] Oliva, M.E., González, M. and Acuria, E. (2004) Metazoan Parasites Fauna as a Biological Tag for the Habitat of the Flounder Hippoglossina macrops from Northern Chile, in a Depth Gradient. Journal of Parasitology, 90, 1374-1377. http://dx.doi.org/10.1645/GE-317R

[41] González, M.T., Barrientos, C. and Moreno, C.A. (2006) Biogeographical Patterns in Endoparasitic Communities of a Marine Fish (Sebastes capensis Gmeli) with Extended Range in the Southern Hemisphere. Journal of Biogeography, 33, 1086-1095. http://dx.doi.org/10.1111/j.1365-2699.2006.01488.x

[42] González, M.T., Vásquez, R. and Acuña, E. (2008) Biogeographic Patterns of Metazoan Parasites of the Bigeye Flounder Hippoglossina macrops in the Southeastern Pacific Coast. Journal of Parasitology, 94, 429-435. http://dx.doi.org/10.1645/GE-1265.1

[43] Henriquez, V.P., González, M.T., Licandeo, R. and Carvajal, J. (2011) Metazoan Parasite Communities of Rock Cod Eleginops maclovinus along Southern Chilean Coast and Their Use as Biological Tags at a Local Spatial Scale. Journal of Fish Biology, 79, 1851-1865. http://dx.doi.org/10.1111/j.1095-8649.2011.03126.x

[44] Sever, T.M., Bayhan, B., Bilge, G. and Taskavak, E. (2009) Diet Composition of Belone belone (Linnaeus, 1761) (Pisces: Belonidae) in the Aegean Sea. Journal of Applied Ichthyology, 25, 702-706. http://dx.doi.org/10.1111/j.1439-0426.2009.01368.x

[45] Zorica, B. and Cikes Kec, V. (2012) Prelminary Observations on Feeding Habits of Garfish Belone belone (L., 1761) in the Adriatic Sea. Croatian Journal of Fisheries, 70, 53-60.

[46] Machado, M.H., Pavanelli, G.C. and Takemoto, R.M. (1996) Structure and Diversity of Endoparasitic Infracommunities and the Trophic Level of Pseudoplatystoma corruscans and Schizodon borelli (Osteichthyes) of the High Paraná River. Memorias do Instituto Oswaldo Cruz, 91, 441-448. http://dx.doi.org/10.1590/S0074-02761996000400010 
[47] Muňoz, G. and Cribb, T.H. (2005) Parasite Communities and Diet of Coris batuensis (Pisces: Labridae) from Lizard Island, Great Barrier Reef. Memoirs of the Queensland Museum, 52, 191-198.

[48] Katsanevakis, S., Lefkaditou, E., Galinou-Mitsoudi, S., Koutsoubas, D. and Zenetos, A. (2008) Molluscan Species of Minor Commercial Interest in Hellenic Seas: Distribution, Exploitation and Conservation Status. Mediterranean Marine Science, 9, 77-118. http://dx.doi.org/10.12681/mms.145

[49] Ben mustapha, K. and Afli, A. (2007) Quelques traits de la biodiversité marine de Tunisie. Proposition d'aires de conservation et de gestion. In: Report of the MedSudMed Expert Consultation on Marine Protected Areas and Fisheries Management. MedSudMed Technical Documents, N 3, GCP/RER/010/ITA/MSM-TD-03, 32-55.

[50] Brandhorst, W. (1977) Les conditions du milieu au large des côtes tunisiennes. Bulletin National d'Océanographie et de Pêche Salammbô, 4, 129-220.

[51] Ben othman, S. (1973) Le sud tunisien (golfe de Gabès), hydrologie, sédimentologie, flore et faune. Thèse de 3ème cycle, Faculté des Sciences de Tunis, 166 p.

[52] Guillaumont, B., Ben mustapha, S., Ben moussa, H., Zaouali, J., Soussi, N., Ben mammou, A. and Cariou, C. (1995) Pollution Impact Study in Gabès Gulf (Tunisia) Using Remote Sensing Data. The Marine Technology Society, 29, 46-58.

[53] Klimpel, S. and Palm, H.W. (2011) Anisakid Nematode (Ascaridoidea) Life Cycles and Distribution: Increasing Zoonotic Potential in the Time of Climate Change? In: Mehlhorn, H., Ed., Progress in Parasitology, Parasitology Research Monographs, Springer, Berlin Heidelberg, 2, 201-222.

[54] Widmann, M. (2013) Impact of Large-Scale Environmental Features Changes on Host-Parasite Interaction in Marine and Freshwater Ecosystems. BioSciences Master Reviews, 1-9.

[55] Poulin, R. and Morand, S. (1999) Geographical Distances and the Similarity among Parasite Communities of Conspecific Host Populations. Parasitology, 119, 369-374. http://dx.doi.org/10.1017/S0031182099004795

[56] Poulin, R. (2003) The Decay of Similarity with Geographical Distance in Parasite Communities of Vertebrate Hosts. Journal of Biogeography, 30, 1609-1615. http://dx.doi.org/10.1046/j.1365-2699.2003.00949.x

[57] MacKenzie, K. (1987) Parasites as Indicators of Host Populations. International Journal for Parasitology, 17, $345-352$. http://dx.doi.org/10.1016/0020-7519(87)90109-3 